\title{
Article
}

\section{A New Empirical Model for Predicting Intermittent and Continuous Drying of "Neve" Melon (Cucumis melo sp.) Seeds}

\author{
Renato Costa da Silva ${ }^{1}\left(\mathbb{D}\right.$, Wilton Pereira da Silva ${ }^{1, * \mathbb{D}}$, Josivanda Palmeira Gomes ${ }^{1}$, \\ Alexandre José de Melo Queiroz ${ }^{1}$, Rossana Maria Feitosa de Figueirêdo ${ }^{1}{ }^{(D)}$, Antonio Gilson Barbosa de Lima ${ }^{1}{ }^{(D)}$, \\ Ana Paula Trindade Rocha ${ }^{1}$, Laerson Duarte da Silva ${ }^{1}$, João Paulo de Lima Ferreira ${ }^{1}$, Dyego da Costa Santos ${ }^{2}$ (D) \\ and Romario Oliveira de Andrade ${ }^{3}$ \\ 1 Department of Agricultural Engineering, Universidade Federal de Campina Grande, Campus I, \\ Campina Grande 58428-830, Brazil; renatinocosta@gmail.com (R.C.d.S.); josivanda@gmail.com (J.P.G.); \\ alexandrejmq@gmail.com (A.J.d.M.Q.); rossanamff@gmail.com (R.M.F.d.F.); \\ antonio.gilson@ufcg.edu.br (A.G.B.d.L.); ana.trindade@ufcg.edu.br (A.P.T.R.); \\ laerson.duarte@gmail.com (L.D.d.S.); jpengenhariaagricola@gmail.com (J.P.d.L.F.) \\ 2 Instituto Federal do Rio Grande do Norte, Natal 59078-970, Brazil; dyego.csantos@gmail.com \\ 3 Instituto Federal de Alagoas, Maceió 57020-600, Brazil; romarioandradeufpb@gmail.com \\ * Correspondence: wiltonps@uol.com.br
}

check for updates

Citation: da Silva, R.C.; da Silva, W.P.; Gomes, J.P.; de Melo Queiroz, A.J.; de Figueirêdo, R.M.F.; de Lima, A.G.B.; Rocha, A.P.T.; da Silva, L.D.; de Lima Ferreira, J.P.; da Costa Santos, D.; et al. A New Empirical Model for Predicting Intermittent and Continuous Drying of "Neve" Melon (Cucumis melo sp.) Seeds. Agriculture 2022, 12, 328. https:// doi.org/10.3390/agriculture 12030328

Academic Editor: Joshua D. Klein

Received: 31 December 2021

Accepted: 21 February 2022

Published: 24 February 2022

Publisher's Note: MDPI stays neutral with regard to jurisdictional claims in published maps and institutional affiliations.

Copyright: (C) 2022 by the authors. Licensee MDPI, Basel, Switzerland. This article is an open access article distributed under the terms and conditions of the Creative Commons Attribution (CC BY) license (https:// creativecommons.org/licenses/by/ $4.0 /)$.

\begin{abstract}
The objective of this work was to intermittently and continuously dry "Neve" melon seeds and study their behavior. The seeds were dried in a fixed-bed dryer at a temperature of $60{ }^{\circ} \mathrm{C}$ under the influence of air velocity of $1 \mathrm{~m} \mathrm{~s}^{-1}$, followed by the prediction of drying kinetics, including that of intermittent processes with its effective time (pseudo-continuous drying) and tempering time (intermittent drying). The dried seeds were crushed to produce flour. The flours were evaluated for physicochemical parameters. To describe drying kinetics (continuous and intermittent drying) of "Neve" melon seeds, empirical models were used, including a new model proposed in this article to describe intermittent drying when the period of intermittence is included in the process. An optimization software was developed (LS Optimizer) and used to determine parameters (and their uncertainties) of the intermittent drying. The parameters of empirical models, used to describe continuous and pseudo-continuous drying, were determined by LAB Fit Curve Fitting Software. The Page model was the one that best fitted in the prediction of the experimental data of continuous and pseudo-continuous drying kinetics of seeds. A new model proposed in this work, based on Page and Lewis equations, was able to predict the kinetics of intermittent drying processes including the tempering time. The flours showed moisture content below $6 \%$, and intermittent drying preserved proteins and lipids more than continuous drying, especially with drying and tempering periods of 10 and $20 \mathrm{~min}$, respectively.
\end{abstract}

Keywords: tempering period; drying kinetics; LS Optimizer; flour characterization

\section{Introduction}

In many industrial processes, water removal is one of the steps involved during production. One of the methods used for this purpose is drying. Drying is a resource of water removal used not only in the paper [1] and pharmaceutical [2] industries, but also in the foodstuff [3] and ceramic [4] industries, being an important method in the conservation of agricultural products after harvest. On the other hand, conscious consumption of products has become an increasingly challenging action today. There is considerable waste of natural resources during agro-industrial processing, so raising the awareness of individuals involved in waste control planning is practically mandatory [5]. Thus, the reduction of both food waste and the energy used for its processing is essential for a product to have a good economic performance in the market. 
The soil and climate of the Northeast region of Brazil are favorable for the cultivation of melon, which is used both for the consumption of the fresh product and for the food industry. In general, in both cases, the seeds are discarded, but this by-product contains many nutrients that are valuable to the human diet. For example, after a proper drying process of these seeds, flour can be produced and used to enrich various food products. The idea of using melon by-products for human consumption has already been used by several researchers, such as King and Onuora [6], who studied and presented in their study various aspects of the extraction of proteins from melon seeds. The researchers found that the protein extracted from melon seeds was characterized by a low level of lysine and relatively large amounts of glutamic acid, aspartic acid and arginine.

In another study [7], which aimed to improve the protein content of bread, wheat flour was mixed with defatted melon seed flour. According to the author of the research, a sensory evaluation revealed that bread with $5 \%$ replacement of melon seed flour did not differ significantly from the control in taste. However, chemical analysis of this product indicated an increase in protein content from $14.6 \%$ (wheat flour) to $21.3 \%$ (blended flours).

To assess the feasibility of using melon seed flour as an ingredient in the manufacture of cakes, researchers [8] developed different formulations, replacing part of the wheat flour with melon seed flour. According to the results of the sensory analysis, there was good acceptance for formulations containing between $10 \%$ and $30 \%$ of melon seed flour. However, the formulation with $10 \%$ melon seed flour was the most accepted by the tasters.

In another study on the potential of using melon waste in cookie production [9], the fruit seeds were sun-dried and then ground in a crusher. Then, a study was carried out replacing part of the wheat flour with melon seed flour. Biscuits containing 2.5\% melon seed flour showed more desirable sensory attributes than control biscuits.

Several studies on the production of melon flour are available in the literature [6-10], and almost all these studies have a common characteristic: the seeds are dried with a continuous supply of heat. However, drying agricultural products requires special care due to the possible reduction of their nutritional components such as proteins, lipids, carbohydrates, bioactive compounds and minerals, which are important for the metabolism of the human body [11]. The utilization of a by-product such as peels and seeds through drying can offer a great diversity of concentrated foods, promoting, in addition to sustainability, a packaged product with a possible beneficial effect on consumer health, besides providing flavor and texture when added to the formulation of other foods. Thus, dry foods derived from by-products can generate products of high nutritional quality with a certain commercial importance [12].

Through research, various artificial drying techniques have been developed over the years, such as convective drying, freeze-drying, dielectric drying, microwave drying, as well as combinations and techniques such as intermittency, which can cause preservation effects on food according to the interests of industry and consumers. Obtaining a highquality product with low energy consumption is a challenge for the existing conventional drying systems, as continuous contact of the product with heat can result in loss of quality during drying. Thus, the use of intermittent drying can both conserve the product and save energy due to the tempering period.

Describing drying (and osmotic dehydration) kinetics is important to observe the behavior of the product during water removal, so predicting the kinetics through empirical and diffusion models is widely used in processes with continuous removal [13-15]. On the other hand, the prediction of intermittent drying kinetics, so that it can be performed including its tempering time, is commonly carried out using numerical diffusion models, due to its complexity, as it is made in [15].

Currently, some researchers are working on methods that facilitate the complete modeling of intermittent drying kinetics using simpler techniques, such as empirical equations, but only two articles have been found so far. Zhao et al. [16] used a polynomial equation with 24 parameters to predict the intermittence in the drying of soybean seeds, while Silva et al. [17] were able to perform the prediction using Page's empirical model, 
adapted to describe the intermittent drying of apple cubes, involving four parameters: two for the drying period and two for the tempering period.

Given the assumption, this study aimed to conduct an experiment comparing the effects of intermittent drying with those of continuous drying, in addition to predicting intermittent drying kinetics including its tempering period. The study was developed in a similar way as proposed by Silva et al. [17] but using a Lewis model to describe the tempering period, decreasing the number of parameters to three, instead of four. To determine the parameters of the proposed model using experimental data, LS Optimizer (http:/ / www.labfit.net/LS.htm)(accessed on 15 December 2021), which is a free software for optimization of differential equations and functions, was developed and used in this research. Also, the effect of the drying conditions on the physicochemical characterization of crushed seeds was analyzed, making it possible to obtain the best experimental condition in the production of melon seed flour, aiming at the aspects of product quality and energy saving.

\section{Materials and methods}

\subsection{Experiment}

The present study was conducted at the Laboratory of Storage and Processing of Agricultural Products (Laboratório de Armazenamento e Processamento de Produtos Agrícolas, LAPPA), from the Federal University of Campina Grande (Universidade Federal de Campina Grande, UFCG), PB, Brazil. The raw material used consisted of "Neve" melon (Cucumis melo sp.) seeds acquired in the street market of the municipality of Juazeiro do Norte-CE. The "Neve" melon seeds were dried in a thin layer in the fixed-bed dryer, with drying air temperature at $60^{\circ} \mathrm{C}$ and air velocity at $1.0 \mathrm{~m} \mathrm{~s}^{-1}$.

Three drying treatments were carried out, two with intermittent drying (intermittency rate of 2/3) and one with continuous drying. The nomenclature "in-inside the dryer" and "out-outside the dryer" was used, under the following conditions: Treatment 1, with 10 min within the dryer, "in", and 20 min in a desiccator, "out", in each cycle; Treatment 2, with 20 min within the dryer, "in", and $40 \mathrm{~min}$ in a desiccator, "out", in each cycle; Treatment 3 , with continuous drying. It is important to mention that the choices for $t_{\text {in }}$ and $t_{\text {out }}$ were made based on the literature on intermittent drying, which generally uses about 5 cycles (or less) to cover the entire process [15-17].

For the tempering period, a desiccator without the presence of silica was used, only to protect the samples from the air current present in the environment, at an average temperature of $28^{\circ} \mathrm{C}$.

Each treatment was carried out in triplicate, and the moisture content was determined by the gravimetric method. After the equilibrium moisture content was reached, the samples were kept in the oven at $105^{\circ} \mathrm{C}$ for $24 \mathrm{~h}$ to obtain the dry mass, used to determine the moisture content according to the methodology described in the manual of the Adolfo Lutz Institute [18]. Thus, with the data of moisture contents on dry basis, the values of the moisture ratio were calculated (Equation (1)).

$$
X^{*}=\frac{X-X_{e}}{X_{i}-X_{e}}
$$

where:

$\mathrm{X}^{*}$-moisture ratio of the product (dimensionless);

$X$-moisture content of the product at a given time (dry basis);

$\mathrm{X}_{\mathrm{i}}$-initial moisture content of the product (dry basis);

$\mathrm{X}_{\mathrm{e}}$ - equilibrium moisture content of the product (dry basis). 


\subsection{Prediction of Continuous Drying}

The continuous (and pseudo-continuous) drying kinetics curves were plotted as a function of drying effective time, and the mathematical models listed in Table 1 were fitted to the experimental data.

Table 1. Mathematical models fitted to the drying kinetic curves.

\begin{tabular}{cccc}
\hline Mathematical Model & Equation & Number & Reference \\
\hline Lewis & $X^{*}=\exp (-$ a.t $)$ & $(2)$ & Lewis [19] \\
Henderson and Pabis & $X^{*}=$ a.exp $(-$ a.t $)$ & $(3)$ & Chinenye et al. [20] \\
Wang and Singh & $X^{*}=1+$ a.t + b.t 2 & $(4)$ & Wang and Singh [21] \\
Peleg & $X^{*}=1-x /(a+b . t)$ & $(5)$ & Peleg [22] \\
Page & $X^{*}=\exp (-$ a.t b) & $(6)$ & Page [23] \\
Silva et al. (ii) & $X *=\exp (-$ a.t - b. $\sqrt{t})$ & $(7)$ & Silva et al. [24] \\
\hline
\end{tabular}

Mathematical models were fitted to the experimental data using the computer programs LAB Fit Curve Fitting [25] for the continuous and pseudo-continuous cases (when the tempering period is eliminated in the description of drying kinetics).

\subsection{Prediction of Intermittent Drying-Direct Problem}

Through a methodology similar to the methodology described by Silva et al. [17], it was possible to perform the prediction of intermittent drying, including the tempering time. This methodology was the only one found in the literature that allows the present study to be conducted. Thus, based on the model established by Silva et al. [17] to predict an intermittent drying process through empirical equations, this article proposes the following model, with a cycle starting at an instant $t_{\mathrm{co}}$ and finishing at $\mathrm{t}_{\mathrm{co}}+\mathrm{t}_{\mathrm{c}}$, with an intermittency ratio of 2/3:

$$
\begin{aligned}
& \text { For } \mathrm{t}_{\mathrm{c} 0} \leq \mathrm{t}<\mathrm{t}_{\mathrm{c} 0}+\frac{\mathrm{tc}}{3}(\text { drying period }) \text { : } \\
& \qquad \begin{array}{l}
\left.\mathrm{X}^{*}(\mathrm{t})=\mathrm{X}^{*}\left(\mathrm{t}_{\mathrm{c} 0}\right) \exp \left[-\mathrm{a}_{1 \text { in }}\left(\mathrm{t}-\mathrm{t}_{\mathrm{c} 0}\right)^{\mathrm{a}_{\text {2in }}}\right)\right]
\end{array}
\end{aligned}
$$

where $\mathrm{a}_{1 \text { in }}$ and $\mathrm{a}_{2 \text { in }}$ denote constants of an equation similar that of Page (Equation (6), in Table 1), for the period in which the samples are inside the dryer, that is, for the drying period. For $\mathrm{t}_{\mathrm{c} 0}+\frac{\mathrm{tc}}{3} \leq \mathrm{t}<\mathrm{t}_{\mathrm{c} 0}+\mathrm{t}_{\mathrm{c}}$ (tempering period):

$$
X^{*}(t)=X^{*}\left(t_{c 0}+\frac{t c}{3}\right) \exp \left[-a_{3 o u t}\left(t-t_{c 0}-\frac{t c}{3}\right)\right]
$$

where $\mathrm{a}_{3 \text { out }}$ denotes a constant of an equation similar that of Lewis (Equation (2), in Table 1), for the period outside the dryer, that is, the tempering period.

It is interesting to note that the final instant of a cycle, that is, $t_{c 0}+t_{c}$, is equal to the initial instant of the following cycle. This shows that there is a concatenation of events inside and outside the dryer in each cycle and of a cycle with the next cycle. A solver was created for the direct problem that implements the proposed model. It interesting to observe that, to determine the parameters $\mathrm{a}_{1 \text { in }}, \mathrm{a}_{2 \text { in }}$ and $\mathrm{a}_{3 \text { out }}$, the LS Optimizer Software was used.

\subsection{Inverse Problem: LS Optimizer Software}

To determine parameters of differential equations and/or functions, for which a set of experimental data is known, the second author of this work developed and freely made available on the Internet the LS Optimizer Software (www.labfit.net/LS.htm) (accessed on 15 December 2021). In other words, the LS Optimizer user must provide a solver for the direct problem, that is, assuming known parameters as well as an experimental dataset (known). For the parameter determination to take place, the solver developed by the user (with the name "solver.exe") must be placed in a folder indicated by the LS Optimizer, according to details presented in the Help file of the optimizer. In a similar way, the file with 
the experimental data set, with the name "exp.txt", must be placed in a folder indicated by the LS. Thus, the LS Optimizer uses the least squares method to determine the model parameters. The mathematical foundations of this software are presented in [26]. On the other hand, the step-by-step integration of the files "solver.exe" and "exp.txt" with the LS Optimizer is explained through the file "Help.pdf" available in the menu "Information", option "How to use LS".

\subsection{Statistical Indicators}

Two criteria were used to determine whether the model had a good fit to the experimental data: coefficient of determination $\left(R^{2}\right)$ and chi-square $\left(\chi^{2}\right)$, expressed in Equation (10). The model that showed a high value of $\mathrm{R}^{2}$, knowing that it can range from 0 to 1 , and a low value of $\chi^{2}$, was considered to have an acceptable fit.

$$
\chi^{2}=\frac{\sum\left(X_{\text {pred }}^{*}-X^{*}{ }_{\text {exp }}\right)^{2}}{D F}
$$

where:

$\mathrm{X}^{*}$ pred-Moisture ratio predicted by the model;

$\mathrm{X}^{*}$ exp-Experimental moisture ratio;

DF: degrees of freedom of the model (number of observations minus the number of model parameters).

\subsection{Flour Characterization}

After drying, the dried seeds were crushed, forming one flour for each treatment, and later characterized to observe the effect of drying on them. The analyses carried out were: moisture content (w.b. \%), water activity, determined by direct measurement in the Aqualab hygrometer, at $25^{\circ} \mathrm{C}$; proteins by the micro-Kjeldahl method described in [27]; and lipids according to the methodology described by Folch et al. [28].

A completely randomized design (CRD) was applied to the experimental data obtained from the analyses performed on the flours, using the computer program ASSISTAT version 7.7 [29] to verify probable statistical differences between the parameters determined. The means comparison test was Tukey test at 5\% probability level.

\section{Results and Discussions}

\subsection{Prediction of Continuous and Pseudo-Continuous Drying Kinetics}

Table 2 shows the values of the parameters, coefficient determination $\left(\mathrm{R}^{2}\right)$ and chisquare $\left(\chi^{2}\right)$ obtained through the models fitted to the data sets of the drying kinetics of "Neve" melon seeds at $60{ }^{\circ} \mathrm{C}$ and air velocity at $1 \mathrm{~m} \mathrm{~s}^{-1}$, using only the effective drying time in treatments 1 and 2 (pseudo-continuous drying). Therefore, the drying kinetics data were studied up to $60 \mathrm{~min}$, justifying the fact that both treatments obtained values close to zero for the moisture ratio at that time.

It can be observed (Table 2) that, among the models studied, only the Wang and Singh model did not obtain $R^{2} \geq 0.99$. Although the $R^{2}$ coefficient was satisfactory (around 0.99), it is not possible and not recommended to use it alone to affirm whether a mathematical model is the best for predicting a given curve. Low values of chi-square $\left(\chi^{2}\right)$ were observed for Treatment 3 (continuous drying) for all models, while for treatments 1 and 2 (intermittent drying), only the Page and Silva et al. (ii) models maintained lower values (order of $10^{-3}$ for all treatments).

The Page model was the one that best fitted to predict the drying kinetics of "Neve" melon seeds, with higher $\mathrm{R}^{2}$ and lower $\chi^{2}$ in all treatments. Mendonça et al. [14], when studying the drying kinetics of crabwood seed, also found that the Page model showed $\mathrm{R}^{2} \geq 0.99$ for continuous drying, being the best model among the evaluated models.

Figure 1 shows the first 60 min of the curves predicted by the Page model fitted to the experimental data of treatments 1 and 2 (only effective time), and treatment 3. 
Table 2. Parameters, coefficient of determination $\left(\mathrm{R}^{2}\right)$ and chi-square $\left(\chi^{2}\right)$ of the models fitted to the drying curves of "Neve" melon seeds.

\begin{tabular}{|c|c|c|c|c|c|}
\hline Model & Treatment & & & & \\
\hline \multirow{4}{*}{ Lewis } & & \multicolumn{2}{|c|}{$\mathrm{a}$} & $R^{2}$ & $x^{2}$ \\
\hline & 1 & \multicolumn{2}{|c|}{0.066} & 0.997 & 0.012 \\
\hline & 2 & \multicolumn{2}{|c|}{0.06566} & 0.997 & 0.011 \\
\hline & 3 & \multicolumn{2}{|c|}{0.05197} & 0.998 & 0.005 \\
\hline \multirow{5}{*}{ Henderson and Pabis } & & a & $\mathrm{b}$ & $\mathrm{R}^{2}$ & $\chi^{2}$ \\
\hline & 1 & 1.031 & 0.068 & 0.996 & 0.0010 \\
\hline & 2 & 1.017 & 0.067 & 0.996 & 0.011 \\
\hline & 3 & 0.979 & 0.050 & 0.997 & 0.004 \\
\hline & & $\mathrm{a}$ & $\mathrm{b}$ & $R^{2}$ & $x^{2}$ \\
\hline \multirow{4}{*}{ Wang and Singh } & 1 & -0.045 & 0.0005 & 0.988 & 0.042 \\
\hline & 2 & -0.044 & 0.0005 & 0.987 & 0.054 \\
\hline & 3 & -0.03962 & 0.0004 & 0.979 & 0.046 \\
\hline & & $\mathrm{a}$ & $\mathrm{b}$ & $\mathrm{R}^{2}$ & $\chi^{2}$ \\
\hline \multirow{4}{*}{ Peleg } & 1 & 13.5 & 0.725 & 0.991 & 0.020 \\
\hline & 2 & 12.99 & 0.752 & 0.991 & 0.023 \\
\hline & 3 & 15.66 & 0.780 & 0.999 & 0.002 \\
\hline & & $\mathrm{a}$ & $\mathrm{b}$ & $\mathrm{R}^{2}$ & $x^{2}$ \\
\hline \multirow{4}{*}{ Page } & 1 & 0.046 & 1.124 & 0.999 & 0.003 \\
\hline & 2 & 0.051 & 1.087 & 0.997 & 0.007 \\
\hline & 3 & 0.0652 & 0.9225 & 0.999 & 0.002 \\
\hline & & a & b & $\mathrm{R}^{2}$ & $x^{2}$ \\
\hline \multirow{3}{*}{ Silva et al. (ii) } & 1 & 0.077 & -0.045 & 0.998 & 0.006 \\
\hline & 2 & 0.073 & -0.029 & 0.997 & 0.009 \\
\hline & 3 & 0.045 & 0.028 & 0.998 & 0.002 \\
\hline
\end{tabular}

Treatments: 1 (Intermittent $\mathrm{t}_{\text {in }}=10 \mathrm{~min}_{\mathrm{out}}=20 \mathrm{~min}$ ); 2 (Intermittent $\mathrm{t}_{\text {in }}=20 \mathrm{~min}_{\mathrm{out}}=40 \mathrm{~min}$ ); and 3 (continuous).
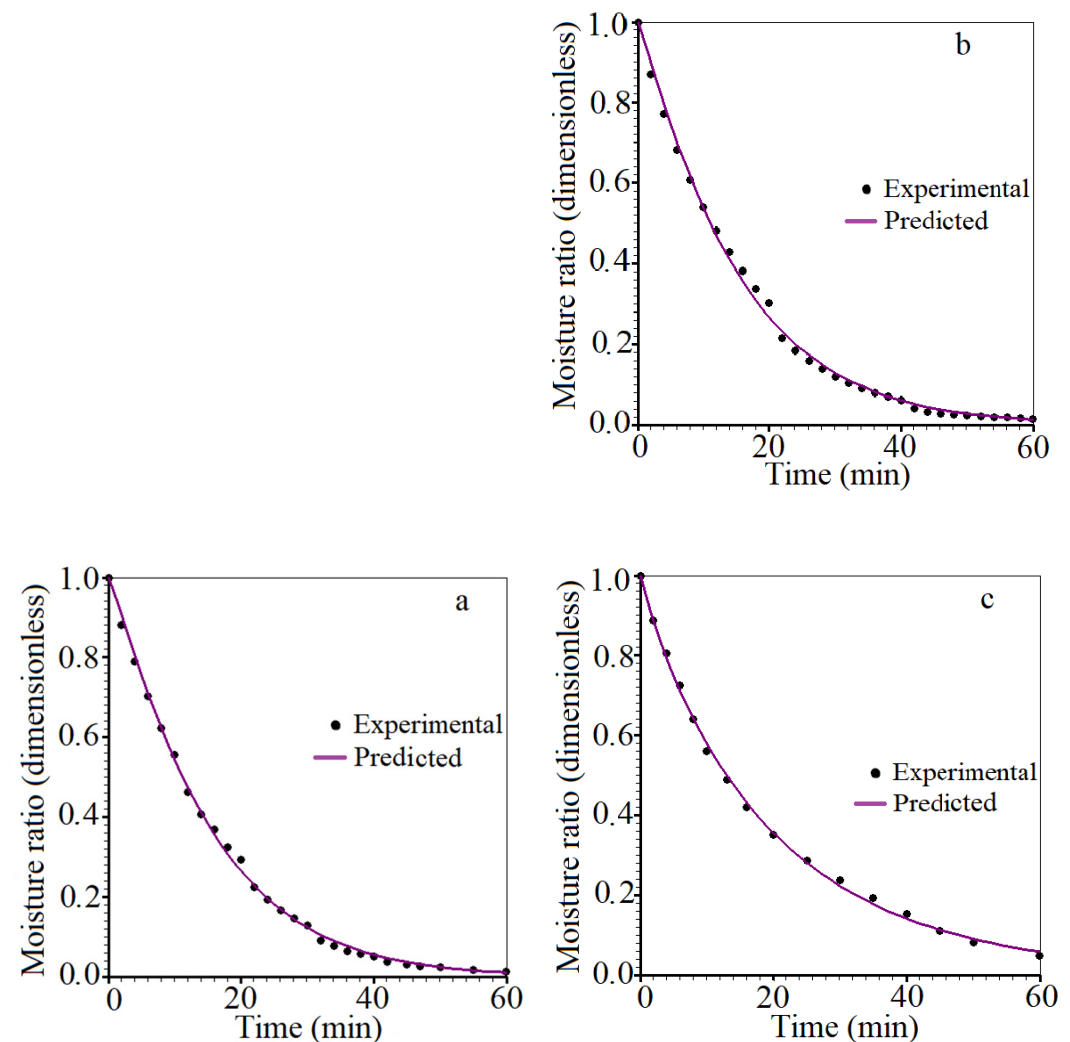

Figure 1. Drying kinetics predicted by the Page model, presenting the effective time of operation: (a) Treatment 1 (Intermittent $t_{\text {in }}=10 \mathrm{~min}$; $t_{\text {out }}=20 \mathrm{~min}$ ); (b) Treatment 2 (Intermittent $t_{\text {in }}=20$ min; $\mathrm{t}_{\text {out }}=40 \mathrm{~min}$ ); (c) Treatment 3 (Continuous).

In addition, Figure 2 presents the superposition of the curves generated by the prediction of the Page model (Figure 1), making it possible to observe the functionality and 
allowing a better comparison of the treatments. At first, it is possible to observe that, at the instant of $60 \mathrm{~min}$, treatments 1 and 2 already have moisture ratio data very close to 0 , while treatment 3 at the same drying time has moisture ratio data of approximately 0.06 .

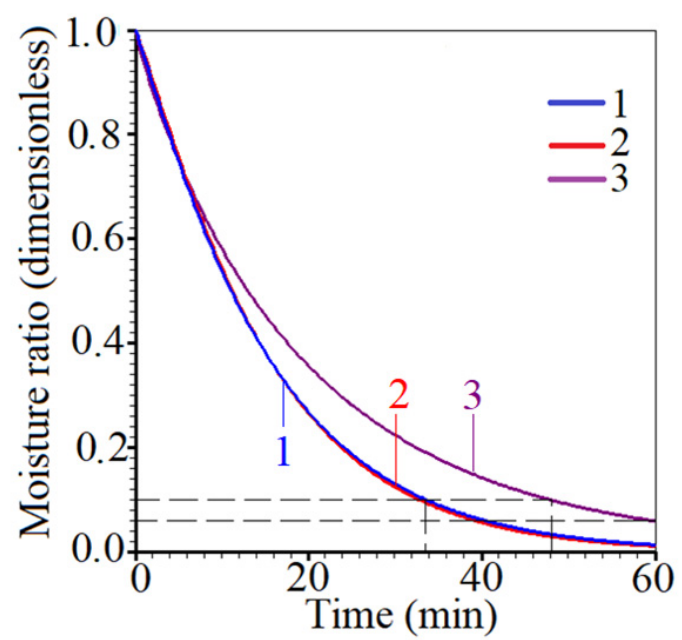

Figure 2. Superposition of the drying curves considering only effective time (continuous and pseudocontinuous) predicted by the Page model. Treatments: 1 (Intermittent $t_{\text {in }}=10$ min $t_{\text {out }}=20 \mathrm{~min}$ ); 2 (Intermittent $\mathrm{t}_{\mathrm{in}}=20 \mathrm{~min} \mathrm{t}_{\mathrm{out}}=40 \mathrm{~min}$ ); and 3 (continuous).

Just as an example, in Figure 2, it is also possible to observe that, to reach the moisture ratio of about 0.1 (close to the end of the process), treatments 1 and 2 (intermittent drying) took approximately $34 \mathrm{~min}$, while treatment 3 (continuous drying) took approximately $48 \mathrm{~min}$ to reach the same point. In other words, treatments 1 and 2 take $29.2 \%$ less time to reach a 0.1 moisture ratio compared to treatment 3 , leading to the conclusion that intermittent drying results in an energy saving of $29.2 \%$ during the drying process compared to continuous drying. This phenomenon is explained by the diffusivity of water inside the product during the intermittent process, because during the tempering treatment, the water contained inside the product tends to migrate to the edges, causing the product to be back in contact with the drying air, requiring less energy for water removal. According to Yang et al. [30], in intermittent drying, the diffusion of water from the inside to the outside of the product and the evaporation of surface water occur in a more balanced way. Martin et al. [31], studying the intermittent drying of peeled cherry coffee, alternating $12 \mathrm{~h}$ in contact with the hot air at $50^{\circ} \mathrm{C}$ with $12 \mathrm{~h}$ of tempering, observed a $24.6 \%$ reduction in the effective time of coffee drying, when compared with continuous drying. Zhu et al. [32], when drying green soybeans intermittently and continuously in order to verify the efficiency of the tempering period in drying, found savings of 23 to $28 \%$ with the reduction of drying time in comparison to continuous drying.

Figure 3 shows the drying rate obtained through Equation (11), which is the derivation with respect to time of the Page model (Equation (6)), in which the parameters obtained in Table 2 for this model were used. According to Ahmed [33], drying rate is the portion of the water mass removed in unit of time based on a given dry product per unit of the drying surface, and it depends on the derivative of the moisture content ratio $(X)$ with respect to drying time $(\mathrm{t})$, which can be obtained from $\mathrm{d} \mathrm{X}^{*} / \mathrm{dt}$, taking into account Equation (1). Thus,

$$
\frac{d X^{*}}{d t}=-a \cdot b \cdot t^{b-1} \cdot \exp \left(-a \cdot t^{b}\right)
$$




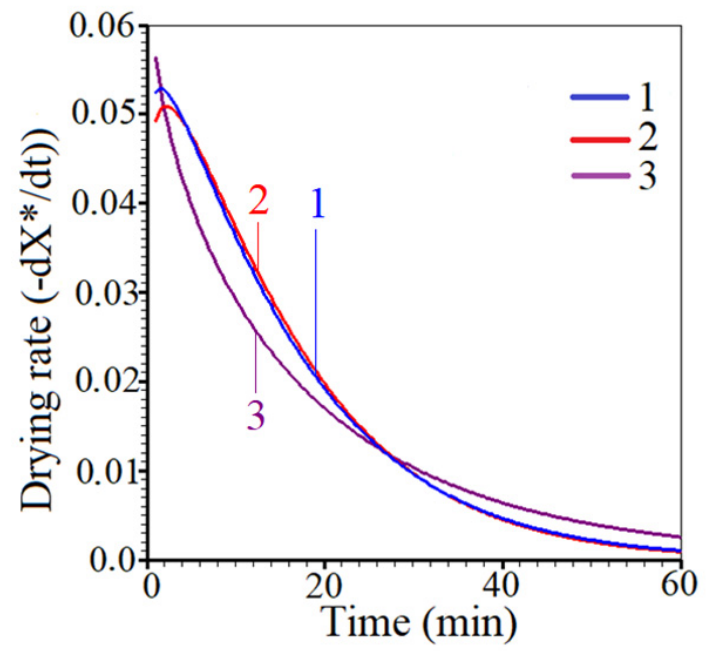

Figure 3. Drying rates using the Page model for treatments 1, 2 and 3, considering only the effective time (continuous and pseudo-continuous). Treatments: 1 (Intermittent $t_{\text {in }}=10 \mathrm{~min} \mathrm{t}_{\text {out }}=20 \mathrm{~min}$ ); 2 (Intermittent $\mathrm{t}_{\mathrm{in}}=20 \mathrm{~min} \mathrm{t}_{\mathrm{out}}=40 \mathrm{~min}$ ); and 3 (continuous).

As additional information, the graphics shown in Figures 1-3 were provided by LAB Fit Curve Fitting Software.

Figure 3 showed that, in all treatments, there are no constant drying rates, but there is a noticeable difference between the drying rates of intermittent drying treatments ( 1 and 2$)$ and the continuous drying treatment (3). Treatments 1 and 2 in the first drying moments tend to show a temporary increase with a subsequent decrease in the moisture rate and are initially superior, while treatment 3 has a totally decreasing rate. Oliveira et al. [34], when studying the physiological quality of corn seeds after drying at different temperatures, observed that the drying rate of corn seeds also shows a decreasing behavior throughout drying at all temperatures studied.

\subsection{Prediction of Intermittent Drying Kinetics Using the Proposed Model}

Table 3 shows the parameters, coefficient of determination $\left(\mathrm{R}^{2}\right)$ and chi-square $\left(\chi^{2}\right)$ of the proposed model fitted to the drying curve of treatment $1\left(t_{\mathrm{in}}=10 \mathrm{~min} ; \mathrm{t}_{\mathrm{out}}=20 \mathrm{~min}\right)$. Two cases are presented. First, it is supposed that the water loss occurs only in the drying period, meaning that $\mathrm{a}_{3 \mathrm{out}}=0$ and, consequently, the proposed model is reduced to only two parameters. Second, it is supposed that the water loss also occurs in the intermittent period, as suggest the experimental data sets and, in this case, three parameters must be determined.

Table 3. Parameters, coefficient of determination $\left(\mathrm{R}^{2}\right)$ and chi-square $\left(\chi^{2}\right)$ of the proposed model (with 2 and 3 parameters) fitted to the data set of treatment 1 (Intermittent $t_{\text {in }}=10$ min $t_{\text {out }}=20 \mathrm{~min}$ ).

\begin{tabular}{|c|c|c|c|c|c|c|}
\hline \multirow{2}{*}{ Number of Parameters } & & \multicolumn{3}{|c|}{ Parameters } & \multirow{2}{*}{$\mathbf{R}^{2}$} & \multirow{2}{*}{$x^{2}$} \\
\hline & & $\mathbf{a}_{1 \mathrm{in}}$ & $\mathbf{a}_{2 \text { in }}$ & $\mathbf{a}_{3 \text { out }}$ & & \\
\hline \multirow[b]{2}{*}{2} & $\mathrm{P}$ & $5.97 \times 10^{-2}$ & 1.037 & - & \multirow{2}{*}{0.997} & \multirow{2}{*}{$1.93 \times 10^{-2}$} \\
\hline & $\mathrm{U}$ & $8.81 \times 10^{-3}$ & $6.60 \times 10^{-2}$ & - & & \\
\hline \multirow[b]{2}{*}{3} & $\mathrm{P}$ & $6.55 \times 10^{-2}$ & 0.948 & $4.68 \times 10^{-3}$ & \multirow[b]{2}{*}{0.997} & \multirow[b]{2}{*}{$1.26 \times 10^{-2}$} \\
\hline & $\mathrm{U}$ & $8.16 \times 10^{-3}$ & $5.78 \times 10^{-2}$ & $9.24 \times 10^{-4}$ & & \\
\hline
\end{tabular}

P-Parameter; U-Uncertainty.

It is observed that the coefficient of determination for describing the curve had values greater than 0.99 , both for two and for three parameters, and the chi-square $\left(\chi^{2}\right)$ of both showed values very close to zero. Since the prediction of intermittent drying kinetics obtained good results, it can be performed using two or three parameters, and the prediction 
with three parameters was the one which obtained lower values of $\chi^{2}$, being more realistic with the physical problem. Silva et al. [35] performed the prediction of intermittent drying kinetics in banana dried at $70{ }^{\circ} \mathrm{C}$ with air velocity of $0.55 \mathrm{~m} \mathrm{~s}^{-1}$ using an optimization program developed by them and obtained $\mathrm{R}^{2}$ values greater than 0.999 and $\chi^{2}$ values of $1.27 \times 10^{-3}, 2.04 \times 10^{-3}$ and $2.71 \times 10^{-3}$ for the tempering intervals of 30,60 and $120 \mathrm{~min}$, respectively, compatible with the results obtained in the present work.

Figure 4 shows the drying kinetic curve of treatment 1, predicted by the proposed model, with two and three parameters.
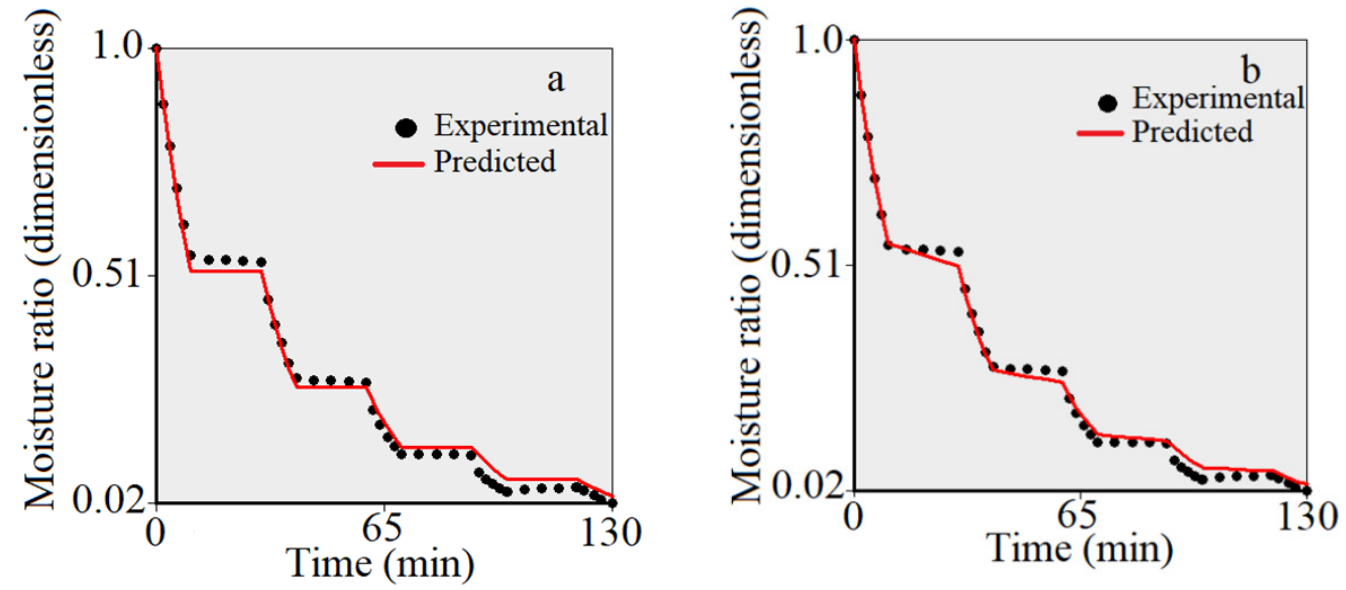

Figure 4. Drying kinetics of treatment 1 (Intermittent $t_{\text {in }}=10 \mathrm{~min}_{\mathrm{out}}=20 \mathrm{~min}$ ) predicted by the proposed model, with: (a) two parameters; (b) three parameters.

For the intermittent process to be completely modeled or predicted, studies consider that the convective mass transfer coefficient should be zero during the tempering period [35], which is equivalent to the value zero for the parameter $a_{3 o u t}$ of the proposed model. According to Figure $4 \mathrm{a}, \mathrm{b}$, it can be observed that, despite the small loss in the amount of water removed from the product during the tempering, this reduction is still noted, causing a small decline in this part of the curve. Possibly, this is the reason for the equation with three parameters to have stood out in the prediction. When using only two parameters, one admits that the tempering period in the kinetics is a horizontal line, and when the third parameter is included, one admits a decrease in the values of the moisture ratio at each experimental point collected in this period. Studying the effectiveness of intermittent drying of green soybean, Zhu et al. [32] also observed that there is loss of water from the product during the tempering period. Thus, the proposed model with three parameters better describes the physical situation studied.

Table 4 shows the parameters, coefficient determination $\left(R^{2}\right)$ and chi-square $\left(\chi^{2}\right)$ of the proposed model fitted to the drying curve of treatment $2\left(t_{\text {in }}=20 \mathrm{~min} ; \mathrm{t}_{\mathrm{out}}=40 \mathrm{~min}\right)$.

Table 4. Parameters, coefficient of determination $\left(\mathrm{R}^{2}\right)$ and chi-square $\left(\chi^{2}\right)$ of the proposed model (with 2 and 3 parameters) fitted to the data set of treatment 2 (Intermittent $t_{\text {in }}=20$ min $t_{\text {out }}=40 \mathrm{~min}$ ).

\begin{tabular}{|c|c|c|c|c|c|c|}
\hline \multirow{2}{*}{ Number of Parameters } & & \multicolumn{3}{|c|}{ Parameters } & \multirow{2}{*}{$\mathbf{R}^{2}$} & \multirow{2}{*}{$x^{2}$} \\
\hline & & $\mathbf{a}_{1 \mathrm{in}}$ & $a_{2 \text { in }}$ & $\mathbf{a}_{3 \text { out }}$ & & \\
\hline \multirow[b]{2}{*}{2} & $\mathrm{P}$ & $6.54 \times 10^{-2}$ & 0.996 & - & \multirow[b]{2}{*}{0.996} & \multirow[b]{2}{*}{$1.53 \times 10^{-2}$} \\
\hline & $\mathrm{U}$ & $5.36 \times 10^{-3}$ & $2.90 \times 10^{-2}$ & - & & \\
\hline \multirow[b]{2}{*}{3} & $\mathrm{P}$ & $7.38 \times 10^{-2}$ & 0.928 & 4.609 & \multirow{2}{*}{0.998} & \multirow{2}{*}{$7.01 \times 10^{-3}$} \\
\hline & $\mathrm{U}$ & $4.27 \times 10^{-3}$ & $2.16 \times 10^{-2}$ & $6.05 \times 10^{-4}$ & & \\
\hline
\end{tabular}

P-Parameter; U—Uncertainty.

The $R^{2}$ values were greater than 0.99 , and the $\chi^{2}$ values were very close to zero. This shows that both have a good representativeness of the experimental values and can be 
used to predict the kinetics of intermittent drying of "Neve" melon seeds dried at $60{ }^{\circ} \mathrm{C}$ with air velocity of $1 \mathrm{~m} \mathrm{~s}^{-1}$. The proposed model with three parameters was the one which obtained the highest coefficient of determination $\left(R^{2}\right)$ and lowest values of chi-square $\left(\chi^{2}\right)$, and therefore best represents the process.

Putranto et al. [36] performed the mathematical modeling of continuous and intermittent convective drying of rice and coffee using the Reaction Engineering Approach (REA) and obtained $\mathrm{R}^{2}$ values $>0.99$ for both products. Silva et al. [37], studying the continuous and intermittent drying of pear at temperatures of 30 and $40{ }^{\circ} \mathrm{C}$, used the solutions of the Fick's diffusion equations to model the intermittent procedure, although in their work, these authors do not clearly show the statistical deviations of the fitting. On the other hand, Holowaty et al. [38], despite having published a paper entitled "Intermittent drying simulation in a deep-bed dryer of yerba maté", used the Page model, but these researchers did not consider the tempering period, as was the case in the present work.

Figure 5 shows the drying kinetics graphs of treatment 2, with prediction of the proposed model with two and three parameters.
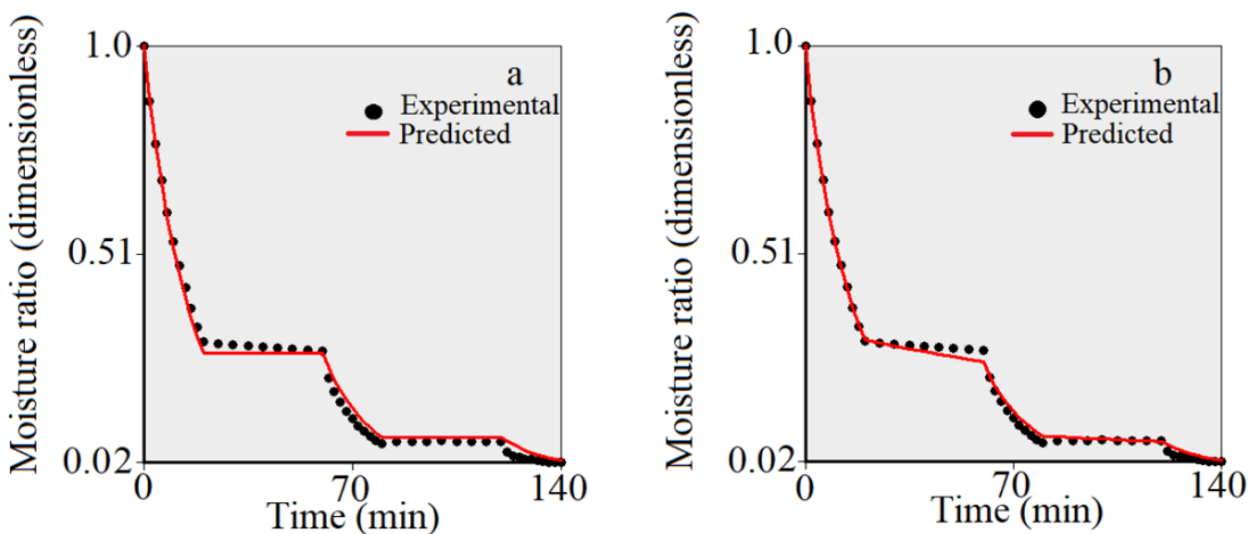

Figure 5. Drying kinetics of treatment 2 (Intermittent $t_{\text {in }}=20 \mathrm{~min}_{\mathrm{out}}=40 \mathrm{~min}$ ) predicted by the proposed model, with: (a) two parameters; (b) three parameters.

As additional information, the graphics shown in Figures 4 and 5 were provided by the LS Optimizer Software.

It is possible to observe in Figure 5 that water loss is more noticeable during the tempering period, because treatment 2 had a longer time interval, thus showing the small decline of the curve, and hence pointing to the fact that the proposed model with three parameters has a better prediction, since the parameter $\mathrm{a}_{3}$ serves to give a small inclination to the curve at the moment of tempering. Lima and Nebra [39], studying intermittency in spheroidal bodies, and Munson-McGee [40], checking the moisture profiles during the intermittent soaking of an oblate spheroid (sorghum grain), consider that there is no water loss during the tempering period. However, treatments show that there is a small loss of water during this period, which could be considered, as in the present work (for example, see Figure 5).

\subsection{Physicochemical Characterization of Crushed Seeds}

Table 5 Presents the results of the physicochemical characterization of fresh seeds and the respective flours of each treatment.

The seeds initially had a free water content of about $61 \%$ and, after drying, there was a considerable reduction for all treatments, with no statistical difference, only between treatments 2 and 3. Despite having spent less time in contact with the drying air, the seeds dried in treatment 1 (intermittent drying) obtained only 1\% more moisture compared to those of treatment 3 (continuous drying), thus reinforcing the efficiency of the process. 
Table 5. Mean values and standard deviation of the physicochemical characterization of fresh seeds and flours obtained through the treatments.

\begin{tabular}{ccccc}
\hline \multirow{2}{*}{ Parameters } & Fresh & \multicolumn{3}{c}{ Treatments } \\
\cline { 3 - 5 } & & $\mathbf{1}$ & $\mathbf{2}$ & $\mathbf{3}$ \\
\hline Moisture content (\%) & $61.0 \mathrm{a} \pm 0.6$ & $5.1 \mathrm{~b} \pm 0.2$ & $4.2 \mathrm{c} \pm 0.4$ & $4.0 \mathrm{c} \pm 0.1$ \\
Water activity, $\mathrm{a}_{\mathrm{w}}(-)$ & $0.992 \mathrm{a} \pm 0.002$ & $0.38 \mathrm{~b} \pm 0.01$ & $0.30 \mathrm{c} \pm 0.02$ & $0.30 \mathrm{c} \pm 0.01$ \\
Proteins (\%) & $11.0 \mathrm{a} \pm 1.3$ & $48.2 \mathrm{~b} \pm 3.3$ & $42.3 \mathrm{c} \pm 2.4$ & $39.6 \mathrm{c} \pm 1.1$ \\
Lipids (\%) & $3.7 \mathrm{a} \pm 0.5$ & $25.5 \mathrm{~b} \pm 0.2$ & $22.2 \mathrm{~d} \pm 0.3$ & $23.5 \mathrm{c} \pm 0.8$ \\
\hline
\end{tabular}

Treatments: 1 (Intermittent $\mathrm{t}_{\mathrm{in}}=10 \mathrm{~min}_{\mathrm{out}}=20 \mathrm{~min}$ ); 2 (Intermittent $\mathrm{t}_{\mathrm{in}}=20 \mathrm{~min}_{\mathrm{out}}=40 \mathrm{~min}$ ); and 3 (continuous) Means followed by the same letter in the rows do not differ statistically from each other. Tukey test was applied at $5 \%$ probability level.

Consequently, after the reduction in the amount of free water, the water activity of the dried seeds was substantially reduced, from 0.99 to 0.30 . Silveira et al. (2016) also reinforce that the low water activity prevents biochemical reactions that depend on this parameter, hence contributing to the conservation of the product, prolonging its shelf life. Pereira et al. (2013) found moisture content of $(8.2 \pm 1.0) \%$ for the flour of acerola (Malpighia glabra L.) residues dried in an oven at $60^{\circ} \mathrm{C}$ for $24 \mathrm{~h}$. Silveira et al. (2016) found moisture content of $(5.7 \pm 0.2) \%$ and water activity $\left(\mathrm{a}_{\mathrm{W}}\right)$ of $0.11 \pm 0.01$ for the flour produced from guava seeds.

Table 5 also shows the values of proteins and lipids of the flours produced through treatments 1, 2 and 3. A concentration in the percentage of proteins and lipids was noted when the seeds were dried to produce flour, due to the concentration of dry mass after the removal of water through drying. Treatment 1 (intermittent drying with $t_{\text {in }}=10 \mathrm{~min}$ and $t_{\text {out }}=20 \mathrm{~min}$ ) was the one that retained the highest amount of proteins, being statistically superior to the other treatments, proving that the methodology used caused less degradation of proteins and greater conservation in the amount of fat, and indicating that the type of drying applied significantly influenced the three applications studied. It is interesting to note that the three treatments were carried out at the same temperature of $60^{\circ} \mathrm{C}$. On the other hand, for the two treatments with intermittent drying, the same intermittence ratio was used (2/3). The only difference in intermittent drying treatments 1 and 2 is related to the times inside and outside the dryer. Thus, it can be concluded that, for the conditions investigated, the best results obtained in the physicochemical characterization are related to times $t_{\text {in }}=10 \mathrm{~min}$ and $t_{\text {out }}=20 \mathrm{~min}$. Kiin-Kabari and Akusu [41] found 25 to $29 \%$ of protein in watermelon seed flour. Olanipekun et al. [42], when analyzing the effect of boiling and roasting on the nutritional composition of common bean (Phaseolus vulgaris) seed flour, obtained values of $24.0,25.2$ and $20.9 \%$ of proteins for boiled, roasted and raw common bean flour, respectively. Malacrida et al. [43], when drying yellow melon seeds at $40{ }^{\circ} \mathrm{C}$, reported $20.1 \%$ of protein and $25.2 \%$ of lipids, stating that they can be used in the development of food products intended for human consumption, provided that the absence of toxic or allergenic substances is proven. This absence of toxic or allergenic substances was verified by several researchers, such as Badejo [7], Da Cunha et al. [8], Ertaş and Aslan [9] and Fall et al. [10].

Furthermore, it would be interesting to note that, although the treatments in this work were carried out on a laboratory scale, such as the experiments available in [6-10], the results obtained suggest the possibility that similar results can be found on an industrial scale, with the use of intermittent drying of melon seeds, obtaining a flour of better nutritional quality with energy savings.

\section{Conclusions}

$>$ Among the models used to predict the drying kinetics of the effective time of intermittent and continuous drying, Page obtained the best results;

$>$ The LS Optimizer program was able to determine parameters of the proposed model for predicting the intermittent drying kinetics including the tempering time; 
$>$ The proposed model with 3 parameters allowed to describe the water loss during the intermittence period and can be preferred when compared to the model with only two parameters, which assumes zero water loss in this period $\left(\mathrm{a}_{3 \mathrm{out}}=0\right)$;

$>$ Intermittent drying of "Neve" melon seeds stood out with lower energy consumption compared to continuous drying, with a $29.2 \%$ shorter effective time in the drying process;

$>$ The water reduction in the product was satisfactory, with low values of water activity, indicating a safe storage in addition to concentrating its protein and lipids in all treatments, especially in treatment 1.

Author Contributions: Conceptualization, W.P.d.S. and R.C.d.S.; methodology, W.P.d.S. and R.C.d.S.; software, W.P.d.S. and A.P.T.R.; validation, W.P.d.S., R.C.d.S. and A.G.B.d.L.; formal analysis, J.P.G., A.J.d.M.Q. and R.M.F.d.F.; investigation, J.P.G., A.P.T.R. and R.M.F.d.F.; resources, A.G.B.d.L., A.P.T.R. and L.D.d.S.; data curation, L.D.d.S.; writing—original draft preparation, L.D.d.S.; writing-review and editing, J.P.d.L.F. and D.d.C.S.; visualization, J.P.d.L.F.; supervision, J.P.d.L.F. and R.O.d.A.; project administration, R.O.d.A. and D.d.C.S.; funding acquisition, J.P.G. and W.P.d.S. All authors have read and agreed to the published version of the manuscript.

Funding: Conselho Nacional de Desenvolvimento Cientifico e Technológico 301708/2019-3; PQ.

Institutional Review Board Statement: Not applicable.

Informed Consent Statement: Not applicable.

Data Availability Statement: Data can be digitized from the graphs or requested to the corresponding author.

Acknowledgments: The second author would like to thank CNPq (Conselho Nacional de Desenvolvimento Científico e Tecnológico) for supporting this study and for his research grant (Process Number 301708/2019-3; PQ-1A).

Conflicts of Interest: On behalf of all authors, the corresponding author states that there is no conflict of interest.

\section{References}

1. Stenström, S. Drying of paper: A review 2000-2018. Dry. Technol. 2020, 38, 825-845. [CrossRef]

2. Pakowski, Z.; Mujumdar, A.S. Drying of Pharmaceutical Products. In Handbook of Industrial Drying; Taylor \& Francis Group: Oxfordshire, UK, 2007. [CrossRef]

3. da Silva, W.P.; e Silva, C.M.D.P.S.; Lins, M.A.A. Determination of expressions for the thermal diffusivity of canned foodstuffs by the inverse method and numerical simulations of heat penetration. Int. J. Food Sci. Technol. 2011, 46, 811-818. [CrossRef]

4. da Silva, W.P.; e Silva, C.M.D.P.S.; da Silva, L.D.; Farias, V.S.O. Drying of clay slabs: Experimental determination and prediction by two-dimensional diffusion models. Ceram. Int. 2013, 39, 7911-7919. [CrossRef]

5. Silva, M.A.; Albuquerque, T.G.; Alves, R.C.; Oliveira, M.B.P.P.; Costa, H.S. Melon (Cucumis melo L.) by-products: Potential food ingredients for novel functional foods? Trends Food Sci. Technol. 2018, 98, 181-189. [CrossRef]

6. King, R.D.; Onuora, J.O. Aspects of Melon Seed Protein Characteristics. Food Chem. 1984, 14, 65-77. [CrossRef]

7. Badejo, O.F. Defatted melon seed flour as partial replacement of wheat flour in bread making. J. Res. Natl. Dev. 2010, 8. [CrossRef]

8. Da Cunha, J.A.; Rolim, P.M.; Damasceno, K.S.F.S.C.; Sousa Júnior, F.C.; Nabas, R.C.; Seabra, L.M.A.J. From seed to flour: Sowing sustainability in the use of cantaloupe melon residue (Cucumis melo L. var. reticulatus). PLoS ONE 2020, 15, e0219229. [CrossRef]

9. Ertaş, N.; Aslan, M. A Study on the Potential of Using Melon Wastes in Biscuit Production. J. Agric. Nat. 2020, $23,1216-1224$. [CrossRef]

10. Fall, J.; Loum, A.; Diago, M.; Diop, A.; Sagne, M.; Jatta, S.; Ndong, D.; Pèlèbè, R.; Diouf, M.; Sheen, S.S. Effects of three varieties of melon seed meal on the growth performance, survival and whole body composition of Oreochromis niloticus fry. J. Fish. Soc. Taiwan 2020, 47, 205-211. [CrossRef]

11. Pham, N.D.; Khan, M.I.; Joardder, M.U.H.; Rahman, M.M.; Mahiudddin, M.; Abesinghe, A.M.N.; Karim, M.A. Quality of plant-based food materials and its prediction during intermittent drying. Food Sci. Nutr. 2019, 59, 1197-1211.

12. Khan, M.I.H.; Wellard, R.M.; Nagy, S.A.; Joardder, M.U.H.; Karim, M.A. Experimental investigation of bound and free water transport process during drying of hygroscopic food material. Int. J. Therm. Sci. 2017, 117, 266-273. [CrossRef]

13. Da Silva, W.P.; Aires, J.E.F.; Castro, D.S.; Silva, C.M.D.P.S.; Gomes, J.P. Numerical description of guava osmotic dehydration including shrinkage and variable effective mass diffusivity. LWT-Food Sci. Technol. 2014, 59, 859-866. [CrossRef]

14. Mendonça, A.P.; Sampaio, P.T.B.; Almeida, F.A.C.; Ferreira, R.F.; Novais, J.M. Determinação das curvas de secagem das sementes de andiroba em secador solar. Rev. Bras. De Eng. Agrícola E Ambient. 2015, 19, 382-387. [CrossRef] 
15. Nosrati, M.; Zare, D.; Nassiri, S.M.; Chen, G.; Jafari, A. Experimental and numerical study of intermittent drying of rough rice in a combined FIR-dryer. Dry. Technol. 2021, 1-13. [CrossRef]

16. Zhao, H.; Yang, Z.; Tao, Z. Drying kinetics of continuous and intermittent heat pump drying of green soybean seeds. Int. J. Food Eng. 2017, 13, 1-15. [CrossRef]

17. Silva, W.P.; Galvão, I.B.; Silva, C.M.D.P.S.; Aires, J.E.F.; Figueirêdo, R.M.F. Empirical model for describing continuous and intermittent drying kinetics of apple pieces. Heat Mass. Transf. 2020, 56, 1263-1274. [CrossRef]

18. Ministério da Saúde. Agência Nacional De Vigilância Sanitária, Métodos Químicos E Físico-Químicos Para Análise De Alimentos; Ministério da Saúde: Brazil, Brasilia, 2005; p. 1017f.

19. Lewis, W.K. The rate of drying of solid materials. J. Ind. Eng. Chem. 1921, 13, 427-432. [CrossRef]

20. Chinenye, N.M.; Ogunlowo, A.S.; Olukunle, O.J. Cocoa bean (Theobroma cacao L.) drying kinetics. Chil. J. Agric. Res. 2010, 70, 633-639. [CrossRef]

21. Wang, C.Y.; Singh, R.P. Use of variable equilibrium moisture content in modeling rice drying. ASAE Pap. 1978, 11, 668-672.

22. Peleg, M. An empirical model for the description of moisture sorption curves. J. Food Sci. 1988, 53, 1216-1219. [CrossRef]

23. Page, C. Factors Influencing the Maximum Rates of Air Drying of Shelled Corn in Thin Layers. Ph.D. Thesis, Purdue University, Lafayette, West Lafayette, IL, USA, 1949.

24. Silva, W.P.; Silva, C.M.D.P.S.; Sousa, J.A.R.; Farias, V.S.O. Empirical and diffusion models to describe water transport into chickpea (Cicer arietinum L.). Int. J. Food Sci. Technol. 2012, 48, 267-273. [CrossRef]

25. Silva, W.P.; Silva, C.M.D.P.S. LAB Fit Curve Fitting Software (Nonlinear Regression and Treatment of Data Program) V 7.2 .51 (1999-2020). Available online: http:/ / www.labfit.net, (accessed on 16 April 2021).

26. Pereira, J.C.A.; da Silva, W.P.; Silva, R.C.; Silva, C.M.D.P.S.; Gomes, J.P. Use of empirical and diffusion models in the description of the process of water absorption by rice. Eng. Computations. 2021, 6, 0264-4401. [CrossRef]

27. AOAC-Association of Official Analytical Chemists. Official Methods of Analysis, 18th ed.; AOAC International: Gaithersburg, MD, USA, 2010; p. 1094f.

28. Folch, J.; Less, M.; Stanley, S. A simple method for the isolation and purification of total lipids from animal tissues. J. Biol. Chemistry. 1957, 226, 497-509. [CrossRef]

29. Silva, F.d.A.S.; Azevedo, C.A.V. The Assistat Software Version 7.7 and its use in the analysis of experimental data. Afr. J. Agric. Res. 2016, 11, 3733-3740.

30. Yang, Z.; Zhu, E.; Zhu, Z.; Wang, J.; Li, S.A. Comparative study on intermittent heat pump drying process of Chinese cabbage (Brassica campestris L. ssp.) seeds. Food Bioprod. Processing. 2013, 91, 381-388. [CrossRef]

31. Martin, S.; Donzeles, S.M.L.; Silva, J.N.; Zanatta, F.L.; Cecon, P.R. Qualidade do café cereja descascado submetido a secagem contínua e intermitente, em secador de camada fixa. Rev. Bras. De Armazenamento Espec. Café 2009, 11, 30-36.

32. Zhu, Z.; Yang, Z.; Wang, F. Experimental research on intermittent heat pump drying with constant and time-variant intermittency ratio. Dry. Technol. 2016, 34, 1630-1640. [CrossRef]

33. Ahmed, M.S.H. Effect of storage temperature and periods on some characteristics of wheat flour quality. Food Nutr. Sci. 2015, 6, 1148-1159. [CrossRef]

34. Oliveira, D.E.C.; Resende, O.; Smaniotto, T.A.S.; Campos, R.C. Qualidade fisiológica de sementes de milho submetidas a diferentes temperaturas na secagem artificial. Glob. Sci. 2016, 9, 25-34. [CrossRef]

35. Silva, W.P.; Rodrigues, A.F.; Silva CM DP, S.; Gomes, J.P. Numerical approach to describe continuous and intermittent drying including the tempering period: Kinetics and spatial distribution of moisture. Dry. Technol. 2017, 35, 272-280. [CrossRef]

36. Putranto, A.; Chen, X.D.; Xiao, Z.; Webley, P.A. Mathematical modeling of intermittent and convective drying of rice and coffee using the reaction engineering approach (REA). J. Food Eng. 2011, 105, 638-646. [CrossRef]

37. Silva, V.; Figueiredo, A.R.; Costa, J.J.; Guiné, R.P.F. Experimental and mathematical study of the discontinuous drying kinetics of pears. J. Food Eng. 2014, 134, 30-36. [CrossRef]

38. Holowaty, S.A.; Ramallo, L.A.; Schmalko, M.E. Intermittent drying simulation in a deep bed dryer of yerba maté. J. Food Eng. 2012, 111, 110-114. [CrossRef]

39. Lima, A.G.B.; Nebra, S.A. Theoretical study of intermittent drying (tempering) in prolate spheroidal bodies. Dry. Technol. 2001, 19, 1569-1589. [CrossRef]

40. Munson-Mcgee, S.H. Moisture profiles during intermittent soaking of an oblate spheroid. J. Food Eng. 2014, 125, 77-83. [CrossRef]

41. Kiin-Kabari, D.B.E.; Akusu, O.M. Effect of processing on the proximate composition, functional properties and storage stability of water melon (Citrullus lanatus) seed flour. Int. J. Biotechnol. Food Sci. 2014, 2, 143-148.

42. Olanipekun, O.T.; Omenna, E.C.; Olapade, O.A.; Suleiman, P.; Omodara, O.G. Effect of boiling and roasting on the nutrient composition of kidney beans seed flour. Sky J. Food Sci. 2015, 4, $24-29$.

43. Malacrida, C.R.; Angelo, P.M.; Andreo, D.; Jorge, N. Composição química e potencial antioxidante de extratos de sementes de melão amarelo em óleo de soja. Rev. Ciência Agronô. 2007, 38, 372-376. 